Portland State University

PDXScholar

Dissertations and Theses

Dissertations and Theses

1977

\title{
Follow-up study of the Child Diagnostic Center
}

\author{
Nancy Ann Peck \\ Portland State University \\ Krystal Angevine \\ Portland State University
}

Follow this and additional works at: https://pdxscholar.library.pdx.edu/open_access_etds

Part of the Social Work Commons

Let us know how access to this document benefits you.

\section{Recommended Citation}

Peck, Nancy Ann and Angevine, Krystal, "Follow-up study of the Child Diagnostic Center" (1977). Dissertations and Theses. Paper 1878.

https://doi.org/10.15760/etd.1870

This Thesis is brought to you for free and open access. It has been accepted for inclusion in Dissertations and Theses by an authorized administrator of PDXScholar. Please contact us if we can make this document more accessible: pdxscholar@pdx.edu. 
FOLIOW-IJP STUDY OF IHE CHIID DIAGNOSTIC CENTER

by

SISTER NANCY ANN PECK, S.S.S.

ard

KRYSTAI ANGEVINE

\begin{abstract}
A practicum submitted in partial fulfillment of the requirements for the degree of
\end{abstract}

MASTER OF SOCIAL WORK

Portland state University

1977 
TO THE OFFICE OF GRADUATE STUDIES AND RESEARCH:

The advisor approved the research practicum of Krystal Angevine and Sister Nancy Ann Peck, S.S.S., presented April 18, 1977. 
TABLE OF CONTENTS

PAGE

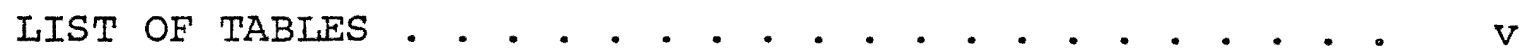

CHAPTER

I INTRODUCTION . . . . . . . . . . . . . . . . 1

II PROGRAM FOR EMOTIONALIY DISTURBED CHILDREN:

THE CHIID DIAGNOSTIC CENTER. . . . . . . . 4

III REVIEW OF THE IITERATURE . . . . . . . . . . 8

Children Labeled Psychotic . . . . . 9

Children Labeled Autistic. . . . . . 16

Children With Other Labels . . . . . 21

Summary. • • • • • • . . . . . . . 24

IV PURPOSE AND METHODOLOGY. . . . . . . . . . 25

Purpose. . . . . . . . . . . . 25

Methodology. . . . . . . . . . 26

V DFSCRIPTION OF THE SAMPLE. • . . . . . . 33

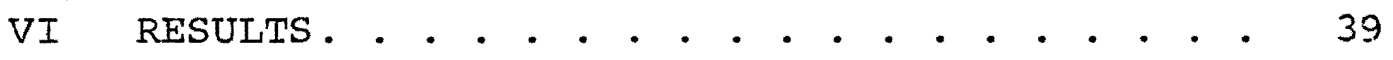

Case Histories . . . . . . . . . . 39

Analysis of Findings . . . . . . . 56 
VII CONCLUSIONS. . . . . . . . . . $6 I$

Discussion . . . . . . . . . . 61

Limitations and Obstacles. . . . . 63

summary. . . . . . . . . . . . 65

BIBLIOGRAPHY . . . . . . . . . . . . . . . 67

APPENDICES :

APPENDIX A: DATA COLLECTION FORM. . . . . . . 70

APPENDIX B: CONSENT TO REIAEASE OF INFORMATION . 71

APPENDIX C: QUESTIONNAIRE . . . . . . . . . 72 


\section{IIST OF TABLES}

TABLE

PAGE

I Types and severity of symptoms of Children

Prior to Entry in the Child Diagnostic

Center..................

II Recommendations Made by the Diagnostic Center. 37

II Treatment Recommendations, Status and

Condition of a Random Sample of Children

Who Attended the CDC From 1968-70. . . . .

IV Recommendations and Implementations for the

Child Diagnostic Center Sample . . . . . . 


\section{CHAPTER I}

\section{INTRODUCTION}

There is an increasing demand for evaluation and follow-up studies to determine service program effectiveness and to provide data to support service expansion. The Oregon state Iegislature, faced with the task of appropriating funds, demands accountability and data to support additional funding. The state is torn between the many needs and limited dollars and must continually choose which way resources will be most effectively utilized. Follow-up and evaluation studies are most helpful in this decision making. In addition, they can also lead to improvement of services.

Over the past several years, Oregon has extensively studied the need for services to children in the state. Eugene Taylor (1965) provided the Mental Health Planning Board with an estimation of service needs for severely emotionally disturbed children. Greenleigh Associates, Inc. (1968) published a study on the child welfare needs and services in Oregon. Most recently Kristin Angell (1976) 
reviewed the historical and political process of developing a comprehensive plan for children's mental health services. The Portland City Club Foundation, Inc. (1971) has stated that "Oregon may well be the best documented state in the nation as to prevalence and needs for treatment of emotional disturbance in children."

In order to document the need for additional treatment centers for severely disturbed children, the oregon Mental Health Division decided to submit a grant to the National Institute of Mental Health to request an extensive, retrospective follow-up study of an innovative diagnostic approach, the Child Diagnostic Center. When the grant was not funded, the state office for Child study and Treatment Centers recruited graduate students to conduct portions of the proposed follow-up study.

As with all follow-up and evaluation the danger always exists that one may find out information that one would really rather not wish to know. The study was begun with the underlying assumption that many recommendations were not carried out due to non-existent resources. The clear message conveyed was that the existence of additional treatment programs for children could prevent, in the long run, the personal destruction of the individual child as 
well as harmful effects to society. In addition, the public would be spared the additional expense of providing adult facilities to house these increasingly very disturbed persons.

There have been many follow-up studies throughout the country dealing with the effectiveness of treatment. This study is unique in that an effort was made to collect historical facts regarding specific recommendations after a six to nine year period. 
CHAPTER II

\section{PROGRAM FOR EMOTIONAILY DISTURBED CHIIDREN THE CHILD DIAGNOSTIC CENTER}

The Mental Health Division received authorization from the Fifty-fourth oregon Legislative Assembly in 1967 to administer a state wide program for emotionally disturbed children. This program became known as the Child Diagnostic Center. The center ran for eighteen months from the end of september 1968 to the end of June 1970 under contract with Edgefield Lodge in Troutdale, Oregon. During this period over 700 applications were submitted for consideration for services at the center. Out of this number 78 were seen for a period of one month each. The children were unevenly divided by sex: 59 were male and 19 were female. They ranged from 3 years to 11 years of age, with a mean age of $8 \frac{1}{2}$ years, a mode of 11 years, and a median of 9 years.

The children came from all parts of the state of oregon, including the following counties: Clackamas, Clatsop, Columbia, Coos, Deschutes, Douglas, Grant, Hood 
River, Josephine, Klamath, Lane, Lincoln, Linn, Malheur, Marion, Multnomah, Polk, Tillamook, Umatilla, Union, and Washington. Multnomah County referred 25 children, the largest number of referrals from a single county. The children were referred from both public and private agencies. Mental health clinics took the lead with 26 referrals, followed by the welfare department with 22 , schools with 8 , Juvenile court and child development clinics each with 6 referrals and other agencies with 1 or 2 referrals each.

The purpose of the Diagnostic Center was threefold: (1) to collect demographic data on the needs and location of children having serious emotional and behavioral problems; (2) to find out how oregon could meet the care and treatment needs of these children; and (3) to provide a framework for the development of comprehensive services for children throughout the state, rather than the existing fragmented approach.

Each child, following admission, resided at the Center for one month, during which time $s /$ he was evaluated in five areas: physical, cognitive and emotional, family life, school, and interpersonal relationships. Up to five children at one time could be in the process of evaluation, with a constant coming and going of children as new admis- 
sions took the place of releasees.

The staff consisted in the beginning of three trained child care workers and a housekeeper. During the following months, according to one of the former staff members, additional staff were added: five child caseworkers, a teacher, a supervisor, and other professional staff as needed.

The staff were involved throughout the Center operation in diagnosing the child, making treatment recommendations, and evaluating the effectiveness of their efforts. Recommendations were made in the areas that the staff saw as most needed for each individual child. These primary recommendations were sometimes followed by secondary recommendations with such words as "if group treatment home is not available then a residential treatment facility will provide for some of the child's needs." In a few isolated cases, recommendations were given for implementation after the completion of primary recommendations; for example, after the child spends six months in St. Mary's Home for Boys he could return to his own home.

Family counseling was also a part of the program while the child was at the center. The family came to Edgefield Lodge, or if distance made this impossible, a 
social worker made home visits. In addition, efforts were made by the social worker to provide liaison with social agencies, schools and others in the community who had been or would be involved with the child.

By design, the staff during the first months of operation developed ideal recommendations, whether or not the community resources existed. In one case (not included in the sample) the recommendation was to place the child in a kibbutz. This resource was nonexistent in oregon. Their purpose in making ideal recommendations was to substantiate the need for additional resources for severely emotionally disturbed children. Later, the recommendations were made with more practical considerations for the best interest of the child. When the funding for the pilot project was terminated, those who had been part of the program felt strongly that the need for such services was even greater than had been originally stated. Their studies estimated that five per cent of Oregon's children needed such treatment and the lack of services and coordination greatly hindered their welfare. To address this acute need, new services under the coordination of the Mental Health Division were developed. The Child Study and Treatment Unit was created for this purpose, parented by the Child Diagnostic Center. 
CHAPTER III

\section{REVIEW OF THE IITERATURE}

A Iiterature review was undertaken in the area of follow-up studies of emotionally disturbed children. The studies in the literature were found to be different from this study in two major ways. First, most of the studies in the literature are concerned with functioning levels at follow-up. The present study, on the other hand, is concerned with an overview of the child's activities since s/he left the Diagnostic Center. Secondly, most of the followup studies in the literature study children specifically labeled psychotic, autistic or childhood schizophrenic. A few studies follow up children labeled antisocial, hysteric, hyperactive, neurotic or behavior disordered. This trend is different from this study because the Diagnostic Center did not label their children. The only criterion for admission to the Diagnostic Center was that the child be "severely disturbed."

This literature review represents the major followup studies conducted in three categories: children labeled 
psychotic, children labeled autistic and children with other labels. Studies were placed in categories according to the labels the authors gave to their sample children. Some studies delineated specific criteria for labeling; others did not.

\section{CHILDREN LABELED PSYCHOTIC}

An early follow-up study was conducted by Freedman and Bender (1957). They presented the case histories of six men who had been diagnosed at the Bellevue Hospital before puberty as childhood schizophrenics. The authors conclude that all of these cases were adult schizophrenics at follow-up. Five of the six cases were getting along in the community in dependent situations at follow-up. The sixth had just been discharged from a mental hospital. of the sample men had received some form of convulsive therapy .

Brown (1960) conducted a follow-up study for the purpose of determining which symptoms best differentiated those children who later did well in treatment from those who made little progress. In order to select the study sample, the researchers reviewed the 73 closed cases of preschool children who had been treated on an outpatient basis 
at the James Jackson Putnam Children's Center and who had been diagnosed as having atypical development (childhood autism or childhood schizophrenia) without organic complications, physical handicaps or a psychotic parent. Available follow-up material on these cases was reviewed, and two groups were selected as research subjects. One group consisted of the 20 children who were doing the "best" at follow-up and the other group consisted of the 20 , children who were doing the "worst." of the 20 "best" cases, 16 were in public school, and the other 4 were doing well in private school. Of the 20 "worst" cases, 11 were known to be in institutions, 3 were believed to be in institutions and 6 were in special classes or in special private schools. The ages at follow-up ranged from 6 to 17 years. In order to find variables which were of prognostic value the cases were rated on a variety of symptoms which had been recorded during the original diagnostic period.

The results showed that the most significant difference between the two groups was their use of materials. Most of the "worst" cases had never been able to use toys appropriately. Another statistically significant difference between the two groups was the depth and scope of their withdrawal. The "worst" cases excluded stimuli and 
withdrew into autoerotic preoccupations or preoccupations with the primitive and bizarre movement of their bodies or objects. Social contacts were minimal.

of the historical and treatment variables that were rated, only one was significant, namely that in the family constellation the "worst" children were more often only children or the first of two children.

There were only two symptoms which were significantly more predominant in the "best" cases. The "best" cases were more likely to identify with animate objects such as dogs or cats, and their aggression was sometimes goal directed.

Brown (1963) followed up 129 children who were at least nine years old in January 1962 and who had been diagnosed during their preschool years as atypical development (infantile psychosis). The children ranged in age from 9 to 22 at follow-up. Follow-up data was collected from a psychiatric evaluation of each child at the children's center or through a report from the child's current therapist. When distance, institutionalization or parental reluctance made a center visit impossible, information was obtained from schools and insţitutions, telephone calls and letters from parents, and telephone calls with the children. The results indicated that with regard to schooling, 
46 children were attending regular school, 14 were attending schools for the retarded, 10 were attending schools for the disturbed, 22 were living in custodial institutions for retarded children, 12 were living in custodial institutions for disturbed children, and 7 were living at home and not attending school. With regard to level of formal learning, 47 were up to or close to their normal age level, 28 were somewhat retarded, 18 were markedly retarded, and 34 had had no formal learning. With regard to psychological adjustment at follow-up, 7 appeared "normal;" 30 appeared "neurotic;" 34 appeared "schizoid;" 25 functioned on only a limited level in a protected environment with socialized behavior and speech; 24 functioned minimally on a preschool level with limited socialized behavior; and 9 children were seen as completely uneducable with no speech, object discrimination or socialized behavior. Regarding treatment, 94 had been treated at the Children's Center, 15 had been treated elsewhere and 20 were untreated. Five of the latter 20 had not been accepted for treatment due to poor prognosis. Bennett and Klein (1966) conducted a follow-up study of 14 subjects who had been diagnosed as childhood schizophrenic. These subjects had been the sample of a five-year follow-up study conducted by Potter and Klein (1937). The 
researchers were unable to locate two of the subjects in New York state. Of the remaining twelve, two had died while patients in a state hospital (one by hanging in 1950 at the age of 29 and the other of a coronary occlusion in 1962 at the age of 31). Of the ten who were located and alive, nine were institutionalized. Two of these nine were in institutions for mental defectives. All nine were diagnosed as "dementia praecox, catatonic or hebephrenic type" at followup. Of the nine in institutions, two had maintained the same level of dysfunction and seven showed regression and deterioration. The one subject in the sample who was not in an institution at follow-up was living alone and maintaining himself by working as a dishwasher. He was found to be a "hesitant and socially awkward man" at follow-up. All of the patients in the sample had been treated by the following succession of treatment modalities as they arose over the years: electric-convulsive therapy, insulin therapy and energetic drug treatment.

Rutter, Greenfield and Lockyer (1967a) (1967b) conducted a five to fifteen year follow-up study of 63 children who had attended the Maudsley Hospital between 1950 and 1958; who had been given an unequivocal diagnosis of childhood psychosis, schizophrenic syndrome, infantile 
autism or any symptoms of these by all consulting psychiatrists; and who had not yet reached puberty. A control group of 61 non-psychotic children who had attended the hospital at the same time were matched with the sample for IQ, age and sex. The mean age of the sample at follow-up was 15 years 7 months, and the mean age of the control group was 16 years 5 months. All 63 psychotic children and 61 controls were seen individually at follow-up. Each child was given a neurological and psychiatric examination and each child was observed in an unstructured situation with other children and with adults at home, school or hospitzl. Detailed past and present information was obtained from the parents.

The results of the study showed that one-third of the psychotic group and one-third of the control group were in long-stay hospitals at follow-up. With regard to paid employment, 2 of the 38 psychotic children aged 16 years or over had paying jobs compared with 12 out of the 36 control children. There was a statistically significant difference in the social adjustment of the two groups at follow-up. Nine of the psychotic children were given "normal" or "good" social adjustrnent ratings compared with 20 of the control group. Thirty-eight of the psychotic group were given 
"poor" or "very poor" ratings compared with 22 of the control group. In the psychotic group 29 were without useful speech at follow-up. Less than half of the psychotic group received as much as two years of schooling. The authors found that the most significant factor related to outcome was the child's response to IQ testing. Children who were untestable on any IQ test or who had an IQ below 60 had a poor outcome. Other factors related to prognosis were: degree of language development, amount of schooling and severity of disorder.

Goldfarb (1970) presented a seven-year prospective follow-up study of 48 schizophrenic children treated in residence at the Henry Ittleson Center for Child Research. The sample consisted of children aged 5 to $8 \frac{1}{2}$ years. Twenty-nine of the children had evidence of organic, neurological dysfunction. Nineteen did not. Thirty-seven were boys, Il were girls. Thirty-four had had two or more years of treatment in residence. Concerning ego-status on admission, 32 were judged to be "very severely impaired" or "severely impaired," 16 were "moderately impaired" and none were "mildly impaired" or "normal." Goldfarb's follow-up data consisted of psychiatric appraisals of ego-status during treatment, placement of the child on discharge and 
on follow-up, and modified appraisals of ego-status at follow-up. The mean age at follow-up was 16 years 8 months. Goldfarb found that at follow-up 24 children were living at home and 24 were living in institutions. With regard to ego-status, 15 were "mildly impaired" to "normal" and 31 were "grossly impaired" at follow-up. The "organic" and "non organic" subclusters of children did not differ significantly with respect to placement at follow-up or social outcome.

The variables which were found to be linked to outcome at follow-up were ego-status and language maturity on admission to residential treatment and the child's response to IQ testing. None of the children judged to be "very severely" or "severely impaired" in ego-status on admission achieved "mildly impaired" or "normal" levels at follow-up. Nine of the ten unscorable children continued to show grossly maladjusted behavior at follow-up. All eight children who were not verbalizing on admission showed grossly disordered behavior at follow-up.

\section{CHILDREN LABELED AUTISTIC}

Kanner (1971) presented a 28-year follow-up study of eleven children who had been diagnosed as autistic at ages 
2 to 8 , and who had been originally described in Kanner's (1943) article "Autistic Disturbances of Affective Contact." At follow-up, two of the eleven could not be located, one had died suddenly in 1966 at 29 years of age, 2 were living with parents, 5 were living in state hospitals and one was living with a guardian. Two of the subjects were employed at follow-up. Three showed no speech at follow-up, and two showed some speech but no spontaneous sentence production. Eisenberg (1956) reported on a follow-up study of 63 children who had been known to the Harriet Lane Home of the Johns Hopkins Hospital for at least 4 years and who had attained an age of 9 or above. The children selected had originally been diagnosed as having the following symptoms of early infantile autism: self-isolation, obsessive insistence on the preservation of sameness and distortions of language function. Data was collected in 30 cases by reexamination plus supplementary reports, in 24 cases from institutional reports and in 9 cases from parents, physicians, and school reports. The median age at follow-up was 15 years. The median length of the follow-up was 9 years. The results of the follow-up showed that 34 children were living in full-time residential settings, and 29 were living at home with parents or foster parents. Of the 
total group of 63,3 were judged as having "good" adjustment, 14 "fair" adjustment and 46 "poor" adjustment.

Eisenberg found that level of speech had an effect on prognosis. Of the 32 children who had developed useful speech by age 5, 16 had a "poor" outcome and 16 a "fair" or "good" outcome at follow-up. Of the 31 nonspeaking children by age 5, 30 had a "poor" outcome and 1 had a "fair" or "good" outcome at follow-up. The difference between the two groups was significant at the .001 level of significance. The study did not reveal any correlation between formal psychiatric treatment and the clinical outcome.

Lotter (1974) conducted a follow-up study for the purpose of describing outcome status and placement history of autistic children and factors related to prognosis. The sample consisted of 32 children who had been identified as having marked autistic behavior by a 1964 epidemiological survey of 8 to 10 year old children living in Middlesex, England. Twenty-two children who had been identified by the survey as having similar, but less marked, features were used as a comparison group. Follow-up data was collected from parent interviews, child interviews and case records. Adequate follow-up information was obtained for 29 out of the 32 autistic children 72 out of the 22 non-autistic 
comparison group.

The follow-up results showed that 4 autistic children were judged as having a "good" outcome, 7 "fair," 4 "poor," and 14 "very poor." Of the comparison group, 8 were judged as having a "good" outcome, 4 "fair," 5 "poor," and 4 "very poor." With regard to living arrangements, 14 of the autistic children were in a long-stay hospital at follow-up compared with 4 in the comparison group. One of the autistic children was employed at follow-up compared with 5 of the comparison group. The researchers did not find a direct relationship between employability and amount of schooling. DeMeyer, Barton, et al. (1973) conducted a follow-up study for the purpose of describing the best measures to predict the fate of autistic children. They followed up 85 boys and $35 \mathrm{girls}$ who had been referred to the Clinical Research Center for Early Childhood Schizophrenia at LaRue D. Carter Memorial Hospital between 1954 and 1969 and who were diagnosed as having infantile autism. The mean age of the sample was $5 \frac{1}{2}$ years at evaluation and 12 years at followup. A "control" group of 26 children was drawn from the nonpsychotic children who had been referred to the same center between 1962 and 1969. The autistic children were placed in three categories: High Autism, Middle Autism and Low 
Autism, according to the degree of symptoms present. At the initial evaluation each child received three independent diagnoses: intellectual, neurological and behavioral. Follow-up data was collected for 94 cases by interviewing and testing each child and for 52 cases by telephone interviews involving a parent.

The follow-up results showed that 90.1 per cent of the autistic children were rated as educationally retarded or incapable of functioning even in a class for the trainable retarded. None of the autistic sample who were adolescents or adults at follow-up held a paying job. Forty-two per cent of the autistic sample were in long-term institutions at follow-up. With regard to overall outcome, 10 per cent were considered to have a "very good" or "good" outcome, 16 per cent "fair," and 74 per cent "poor" or "very poor." All Middle and Low Autistic children were autistically withdrawn at evaluation, and 80 per cent of these remained withdrawn at follow-up. Approximately 75 per cent of the Middle and Low Autistic children were mute or echolalic at evaluation. By follow-up half of these children had developed some communicative speech, although at a level much below that expected for their age.

DeMeyer, et al. found that the best predictor of work 
or school rating at follow-up was the work/school rating at evaluation. Severity of illness was the next best predictor, followed by social rating, speech and the brain dysfunction index .

\section{CHIIDREN WITH OTHER LABELS}

Lo (1973) followed up 42 children diagnosed as neurotic and 30 children diagnosed as behavior disordered between June 1967 and June 1971 at the Yaumatei Psychiatric Centre, Hong Kong. Neurotic symptoms were considered to be anxiety; depression; phobias; obsessional, hysterical and somatic symptoms; irritability and tension manipulations (in the absence of psychotic or organic features). The term behavior disorder was used to refer to symptoms of hostile disobedience, destructiveness, aggressiveness, truancy, lying, stealing and running away from home (in the absence of psychotic or organic features). The mean follow-up period for the neurotic group was 2.7 years and for the behavior disorder group 2.9 years. Eight neurotic children and 12 behavior disorder children were still attending the Centre at follow-up. Data for the remaining children was collected from parent and child interviews at the centre or home visits by a social worker. 
Results showed that 78.6 per cent of the neurotic children compared with 53.3 per cent of the behavior disorder children were symptom-free or significantly improved at follow-up. This was significant at the .05 level of significance. Two factors were seen to significantly influence prognosis: sex (more boys improved) and duration of illness before attending the Centre.

Davids (1975) conducted a retrospective follow-up study for the purpose of determining the relationship between the diagnosis of a case during residential treatment and the follow-up evaluation on that case after discharge and for the purpose of evaluating the effectiveness of Rimland's (1964) Diagnostic Check List for Behavior Disturbed Children (DCL) in differentiating among autistic, non-autistic psychotic, and non-psychotic cases. In order to draw the sample, Davids rated the files of male children who had attended the Bradley Hospital Residential Treatment Center according to the behavioral symptoms on the DCL. In addition, parents were mailed DCL forms and asked to complete the items from memory according to how they remembered the child at admission to the Bradley Hospital. The sample was then divided into four groups: (I) 21 children who were labeled with a psychotic diagnosis between 1955 
and 1964, (II) 20 children who were labeled with a psychotic diagnosis between 1945 and 1954, (III) 20 children who were labeled behavior disorder between 1955 and 1964, and (IV) 5 children who were labeled neurotic between 1955 and 1964. The mean ages at the time of admission were: 8 years in Groups I and II, 9 years in Group III and 10 years in Group IV. The follow-up data was obtained by mailing a follow-up questionnaire to parents or to agencies with custody of the cases where there was no parent available. Davids found that 17 per cent of the psychotic groups compared with 56 per cent of the non-psychotic groups had had no further treatment after leaving the residential treatment center. This was significant at the .05 level of significance. With regard to living situation, Davids found that 39 per cent of the psychotic groups compared with 73 per cent of the non-psychotic groups were living at home at follow-up. This was significant at the .05 level of significance. With regard to schooling, 44 per cent of the psychotic group were attending school at follow-up compared with 81 per cent of the non-psychotic group. This was significant at the .05 level of significance. In addition, Davids found that Rimland's DCL was useful in differentiating between autistic, non-autistic psychotic 
and non-psychotic children.

\section{SUMMAKY}

The literature reflects a guarded to poor prognosis for children labeled psychotic or autistic. Of the variables studied, the following were found to be related to poor prognosis in psychotic children: limited language development, severity of disorder, inappropriate use of toys, severity of withdrawal, poor response to IQ testing and limited schooling. Variables found to be related to poor prognosis in autistic children were: poor speech development, severity of withdrawal, poor work/school rating and poor social rating. 
CHAPTER IV

PURPOSE AND METHODOLOGY

\section{PURPOSE}

The purpose of this research project was twofold:

(1) To investigate what happened to the children who took part in the Diagnostic Center.

(2) To assess whether or not the recommendations of the Diagnostic Center were followed.

The first objective was only partially followed

because the only children who were located for follow-up were those who had remained in the Children's Services Division system. Thus, no generalization can be made about what happened to the entire population.

The second objective was also only partially carried out for the above reason. In addition, interpretation of the data related to the second objective is difficult because it is not clear whether a failure to have followed the recommendations was due to a decision not to follow them by a child's guardian or to a lack of resources. The Child Study and Treatment Unit of the Oregon 
State Mental Health Division sponsored this study for the purpose of gaining information which would be used for future program planning and funding decisions.

\section{METHODOLOGY}

In the spring of 1976 Ms. Krystal Angevine and Sister Nancy Peck agreed to carry out a follow-up study for the Child Study and Treatment Unit of the Oregon Mental Health Division. At that time a research project was designed which entailed drawing a random sample of 20 children from the population of 78 who had attended the Diagnostic Center and interviewing the parent, guardian or social worker of each sample child. This research design was changed in November of 1976 due to many obstacles which will be discussed later in this paper. The new design entailed following up a sample of 10 children rather than 20 and collecting data by searching the Children's Services Division files rather than by interviewing guardians.

Following is an account of the actual work which took place on this project from the time it began in the spring of 1976 until its completion in the spring of 1977. Dates are provided so that the reader can follow the project chronologically. 
In April of 1.976 a meeting was held with Krystal Angevine and Sister Nancy Peck, researchers; Ms. Nancy Koroloff, assistant professor of social work, Portland State University, and faculty advisor; and Ms. Mary Hoyt, manager of the Child Study and Treatment Unit of the Oregon State Mental Health Division. During the meeting the purpose of the project, time frame, responsibilities and remunerations were discussed. It was decided that the Child Study and Treatment Unit would procure releases on the records of each child in the sample, and they would obtain each parent's or guardian's current address. The researchers would carry out the actual data collection, analysis of data, literature review and write-up. Remunerations would be in the form of travel money for interviews and typing. The time frame for the collection and analysis of data was set for the summer of 1976 so that the project would be completed by March of 1977 .

The researchers began the project by reviewing the records which had been kept on each child by the Diagnostic Center. These 78 records were in the possession of the Child Study and Treatment Urit. Information on each case was collected with regard to sex, birthdate, age at admission, IQ, physical problems, referral agency, primary 
recommendations, secondary recommendations and future recommendations. (See Appendix A.) A number was affixed to each case and all names removed in order to insure confidentiality. Thirteen cases were eliminated from the population because they did not include complete recommendations. This left 65 cases from which to draw the sample. In May, a sample of 20 and an alternate sample of 10 was drawn from a random numbers table. These names were turned over to the Child Study and Treatment Unit with the expectation that they would obtain releases on the records of the children and addresses of their parents or guardians.

Several attempts were made by the Child study and Treatment Unit to procure the releases and addresses for the researchers. A law student employed in the Administrative Services Office of the Mental Health Division was asked to review the confidentiality statutes of the Oregon Mental Health Division and the Children's Services Division in order to determine the procedure the researchers needed to follow in order to insure confidentiality. The result of this inquiry was that the researchers could proceed if a release of information form was obtained for each child. A sample release of information form was designed and submitted to the Oregon Attorney General's office for approval. (See 
Appendix B.)

In addition, the Child Study and Treatment Unit contacted the manager of the Data support Services Section of the Mental Health Division in order to ascertain the feasibility of using the computerized Mental Health Information System as a means of locating the sample children. Permission to use the system was obtained from the Administrator of the Mental Health Division. Four names of sample children were run through the Mental Health Information System computer as a trial. No information existed on these parents.

By mid-october, six months had elapsed with no information produced by the sponsoring agency. The researchers spent the summer of 1976 researching the literature, writing the interview schedule and checking with the sponsoring agency on the status of their efforts. The interview schedule was designed to gather information on what had happened to each child since their residence at the Diagnostic Center as well as specific information on whether or not the recommendations had been followed. Questions were designed to gather information in the five areas in which recommendations had been made by the Diagnostic Center, including: living arrangements, schooling, family 
counseling or treatment, individual counseling or treatment and physical problems. In addition, questions were developed pertaining to follow-up information such as trouble with the law, trouble with the school, significant happenings, relationships with others, and future prognosis. (See Appendix C.)

In October Ms. Nancy Koroloff, faculty advisor, conferred with the manager of the Mental Health Unit of the Oregon Children's Services Division. A letter was drafted requesting information from the regional Children's Services Division offices on the whereabouts of the twenty sample and ten alternate sample children. The Child study and Treatment Unit sent this letter. By mid-November the Children's Services Division offices had responded. Ten of the twenty sample children had been located.

In mid-November a decision was made by the researchers to change the study design. This decision was made because an attempt to follow the original design would have extended the project past the date required for submission of the practicum. The new design entailed following up the ten children who had been located by the Children's Services Division rather than the twenty children who had been chosen randomly and gathering data by searching the Chil- 
dren's Services files rather than by interviewing the guardians. The revision of the research design severely limited the interpretation of any data which was collected. These limitations are discussed later in this paper. In mid-November a release of information form for each child was signed by the Administrator of the Children's Services Division. This gave the researchers access to the Children's Services Division files on the ten sample children and enabled the researchers to begin collecting the data. It was discovered that the information received from the Children's Services Division offices was not accurate. The children's files were not located in the offices which had been indicated.

The Administrative Assistant of Region I of the Children's Services Division undertook the task of helping the researchers locate the children by searching the Children's Services Division master file. Seven of the ten sample children were located.

During the period between December 18, 1976 and January 9, 1977 the data was collected by one of two methods: by directly searching each file which was located in Multnomah County or by calling the Children's Services Division caseworker and having her/him search the file if 
the case was located outside Multnomah County. The original interview schedule was used as the means of gathering the data.

In February of 1977 the researchers began compiling the data and writing the research report. 
CHAPTER V

\section{DESCRIPTION OF THE SAMPLE}

The sample consisted of ten children. Nine of the children were boys; one was a girl. All ten were caucasian. The sample children were referred to the Child Diagnostic Center from throughout the state of oregon. Two children were referred from Multnomah County, and one child was referred from each of the following counties: Coos, Josephine, Hood River, Washington, Tillamook, Iane, Klamath, and Iinn. The mean age at admission was 9.4 years. The range of ages at admission was 6 years 9 months to 11 years 10 months.

The children who took part in the Diagnostic Center were considered to be "severely disturbed." They were not given psychiatric labels. Table I, developed by the Diagnostic Center, shows the types and severity of symptoms of the children prior to their admittance to the Diagnostic Center. 
TABLE I

TYPES AND SEVERITY OF SYMPIOMS OF CHILDREN PRIOR TO ENTRY IN TIEE CHIID DIAGNOSTIC CEN'IER

\begin{tabular}{|c|c|c|c|c|c|c|c|c|c|c|}
\hline \multirow[b]{2}{*}{ Symption } & \multicolumn{10}{|c|}{ Child's Number, Sex and Age } \\
\hline & $\begin{array}{c}\text { 非 } \\
\text { Boy } \\
\text { B yrs }\end{array}$ & $\begin{array}{l}\# 2 \\
\text { Boy } \\
6 \text { yrs }\end{array}$ & $\begin{array}{c}\text { \#3 } \\
\text { Boy } \\
8 \text { yrs }\end{array}$ & $\begin{array}{c}\text { \#4 } \\
\text { Gir } 1 \\
11 \text { yrs }\end{array}$ & $\begin{array}{c}\$ 5 \\
\text { Boy } \\
11 \text { yrs }\end{array}$ & $\begin{array}{l}\text { \#6 } \\
\text { BOy } \\
10 \mathrm{yrs}\end{array}$ & $\begin{array}{c}\# 7 \\
\text { Boy } \\
8 \text { yrs }\end{array}$ & $\begin{array}{c}\# 8 \\
\text { Boy } \\
10 \text { yrs }\end{array}$ & $\begin{array}{c}\text { \#9 } \\
\text { Boy } \\
7 \text { yrs }\end{array}$ & $\begin{array}{c}\# 10 \\
\text { Boy } \\
7 \text { yrs }\end{array}$ \\
\hline $\begin{array}{l}\text { Lags in Development of } \\
\text { Seif-Help and Social skills }\end{array}$ & II & III & II & II & $-m-$ & $m-m$ & II & I & I & III \\
\hline Learning Problems & III & III & II & II & II & $--\infty$ & II & II & $\mathbf{I}$ & -- \\
\hline $\begin{array}{l}\text { Assaultive, Destructive, } \\
\text { Firesetting, stealing }\end{array}$ & III & $\cdots$ & $-\infty$ & II & III & $\operatorname{III}$ & I & II & III & I \\
\hline $\begin{array}{l}\text { Bizarre, Psychotic-like, } \\
\text { nutistic-like, Fantasizing }\end{array}$ & I & III & $-\cdots$ & II & $-\cdots$ & -- & $\mathbf{I}$ & $-\cdots$ & $\cdots$ & II \\
\hline $\begin{array}{l}\text { Mistrustful, Withdrawn, } \\
\text { Isolated, Aloof }\end{array}$ & -- & III & II & II & $-m$ & -- & $\mathbf{I}$ & I & --- & $-\infty$ \\
\hline Self-Destructive & --- & --- & $-\infty$ & --- & II & --- & -- & --- & $-m-$ & I \\
\hline llyperactive & $\operatorname{III}$ & -- & I & II & II & II & $\mathbf{I}$ & $\mathbf{I}$ & $\operatorname{III}$ & III \\
\hline $\begin{array}{l}\text { Negative, Disobedient, } \\
\text { Unmanageable }\end{array}$ & II & II & III & II & III & III & II & I & III & III \\
\hline $\begin{array}{l}\text { Fearful, Night Terrors, } \\
\text { Enuretic, Encopretic }\end{array}$ & I & -- & III & II & II & -- & -- & II & -- & $\mathbf{I}$ \\
\hline
\end{tabular}

Kex

Blank (--) No prior symptoms

I Mild degree or very occasional

II Extended, moderate degree or occasrional severe 
In Table I the symbol, I, indicates that the child expressed the indicated behavior to a mild or very occasional degree. The symbol, II, indicates that the child expressed the indicated behavior to an extended, moderate degree or occasional, severe degree. The symbol, III, indicates that the child expressed the indicated behavior to a frequent, severe degree for many years. As seen in Table I, to a moderate or severe degree 9 children were disobedient and unmanageable; 7 had learning problems; 6 were hyperactive; 6 had lags in self-help and social skills; 4 had assaultive, destructive, firesetting or stealing behavior: 4 were fearful, enuretic or encopretic; 3 had bizarre, psychotic-like behavior; 3 were mistrustful and withdrawn; and one was self-destructive.

At the Diagnostic Center nine sample children were tested for IQ. One child was untestable. Of the nine who were tested, the mean IQ was 97 . The IQ range was 70 to 118 . The Diagnostic Center made recommendations for each child. Primary recommendations indicated the optimal treatment recommendation. Secondary recommendations indicated the second choice of treatment if the first was not available. Future recommendations indicated treatment which would follow the primary recommendation chronologically. 
Recommendations were made in the areas of living arrangements, schooling, medical needs, counseling and treatment, and family counseling and treatment. Table II shows the recommendations which were made for the sample children by the Diagnostic Center. (See Table II, page 37.)

As indicated in Table II, all sample children were given primary recommendations, two children were given secondary recommendations, and no children were given future recommendations. With regard to primary recommendations, 4 children were recommended for placement in a small treatment group home, 3 for placement in residential treatment (one of these would return to his family on weekends) and 3 to remain in the family and attend a day treatment program. Family therapy was recommended for 4 families. A special or remedial classroom was suggested for 9 children. The discontinuation of medication for behavior problems was recommended for two children.

The reader is reminded that the only children who were included in the sample for this research study were those who had had some contact with the Oregon Children's Services Division, because releases were only obtained for Children's Services Division files. 
TABLE II

RECOMMENDATIONS MADE BY THE DIAGNOSTIC CENTER

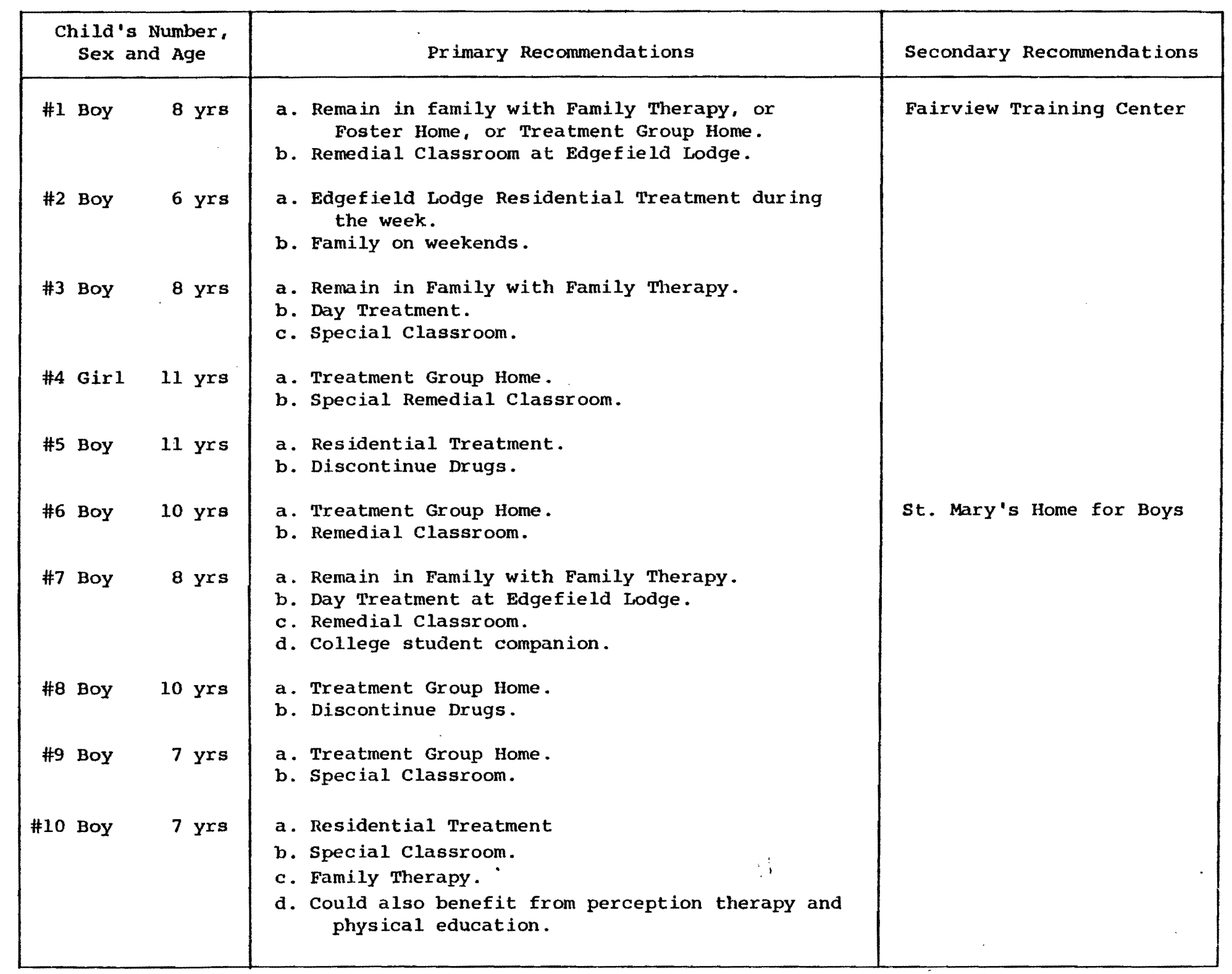


A comparison of the population and the sample indicates that there are some differences between the make-up of the two groups. The population has a one-to-three ratio of girls to boys, whereas the sample has a one-to-ten ratio of girls to boys. The mean age of the population is 8.5 years with a range of 3 to 11 years, whereas the mean age of the sample is 9.4 years with a range of 6.75 to 11.82 years. 
CHAPTER VI

RESULTS

\section{CASE HISTORIES}

The following are case histories of the ten children in the sample. The names have been changed to protect their identity. All the information relating to case history both prior and during the child's evaluation at the Child Diagnostic Center came from Center records. Follow-up information was gathered from various sources including Children's Services Division, personal interviews, and Center reports.

\section{Case One}

Allen, male, entered the Child Diagnostic Center in the fall of 1968 at the age of eight years. He was referred to the program by the welfare and juvenile courts of a midWillamette Valley county.

The family was known to several service agencies, both social and medical. His parents had a long history of marital problems which seemed to contribute to the destruc- 
tive behavior of Allen. Examples of his behavior problems included setting fires and torturing animals. In his school he attended a special program and seemed to be able to be gentle and manageable.

At the Diagnostic Center Allen responded well, appeared manageable, and his destructive behavior stopped. He seemed to have high intellectual potential.

Recommendations for Allen included returning to his home where it was felt that with the necessary support in household and child management, the parents could handle Allen adequately. A special remedial education classroom was seen as a necessity. A secondary recommendation was to place Allen in a foster home or treatment group home with sufficiently trained staff to achieve the recommended treatment goals.

Allen was placed in a foster home following release and attended special classes. His family received counseling from a court-appointed counselor who met with them on a weekly basis. Children's Services Division closed the case several months following release from the Diagnostic Center and Allen returned to his own home. There is no other record for this child. 


\section{Case Two}

Bob, male, entered the Child Diagnostic center in early 1969 at the age of six years. He was referred by a family service clinic on the coast. Bob presented problems of deficient speech development and repetitive activity and seemed to be unaware of persons and activities within his environment. He was known to make noises and facial expressions without any relationship to his environment. Bob had been diagnosed by a psychiatrist in 1968 as being a cáse of childhood schizophrenia.

During his stay at the Diagnostic Center it became clear that Bob was acutely aware of his surroundings and those about him, but because of his great fear of rejection and abandonment he avoided involvement. As time progressed, he was able to take part in the Center activities with more enjoyment and began to interact with his peers.

Recommendation was for residential treatment such as Edgefield Lodge. This recommendation called for his parents' participation. Since they lived on the coast they would have to move to Multnomah County in order for their child to take part in the program.

Bob returned to live with his family upon release. The family refused to move to the Portland area so he was 
ineligible for placement at Edgefield Lodge. He attended a private kindergarten while awaiting admittance to Parry Center. Ten months after release from the Diagnostic Center he was placed at Parry Center and had special remedial classes, tutoring, and counseling. His parents received marital counseling through a local mental health clinic. They also received additional supportive counseling from Parry Center for one year. Their marriage split up, each remarried and both couples began living together. Bob has made no progress since admission to Parry Center and is described as autistic, needing to be permanently institutionalized. He will remain at Parry Center for as long as possible and the next alternative will be Fairview.

\section{Case Three}

Chris, male, was admitted to the Child Diagnostic Center in the spring of 1969 at the age of eight years. He was referred by a mental health clinic in the portland area.

Chris had a behavior pattern which was "characterized as grossly passive-dependent upon adults, especially family adults." A feeling of inability to meet the demands of his environment could account for his behavior. Often in his 
school setting he would panic when stress to perform was placed upon him and he became unable to do his work. Chris seemed to gain satisfaction in acting as a "helpless, sickly, effeminate who utilized infantile methods in stressful situations."

In the Child Diagnostic Center Chris appeared to make an effort to move towards more independent and aggressive behavior.

The recommendation made for Chris involved his family and their system of operating in relationship to their child. They had over-reacted to his seizures and supported his dependent and helpless role. Family counseling and therapeutic day care within a structured and well programmed classroom were seen as essential for improvment with this child.

Sources reported that the child died in ontario; however, the researchers were unable to confirm this report.

\section{Case Four}

Diane, female, was admitted to the Child Diagnostic Center in the early summer of 1969 at the age of eleven years. She was referred by a school district in a small community in the mid-Willamette Valley. 
Diane was tutored at home for almost two years due to her bizarre behavior and excessive fantasy. Her parents had been concerned about her behavior since she was a very young child and discussed with various agencies the possibility of help for her. However, they were suspicious of help and never followed through on any type of residential care suggested for the child.

At the Child Diagnostic Center Diane showed herself to be a very charming child with superior intelligence. She seemed to be a very lonely child who saw herself as evil, unable to live up to the high standards she had set for herself, and was close to despair.

The recommendations for Diane were residential treatment, long-term group home, and a special class designed for emotionally disturbed children.

Diane went to Christie School for Girls and made great improvement. It appeared that she would need such stability for some time. The only known detail of the case after Christie School for Girls was the information that at the age of eighteen she was referred to Children's Services Division by the Public Welfare Department on the coast; she was unmarried, on welfare, and pregnant. 


\section{Case Five}

Edward, male, entered the Child Diagnostic Center in the summer of 1969 at the age of eleven years. He was referred by the welfare department in the Eugene area. Edward was well known to several agencies due to his very dangerous and destructive behavior. This ranged from stabbing, choking, and other types of assaultive behavior: property destruction and stealing; threats of harm toward self and others; and running away. Despite his behavior he was seen as a charming boy with many skills and great potential. His parents were unable to cope with Edward and did much to contribute to his behavior problems through their inconsistency, teasing, erratic behavior, and occasional violent parental reactions. In growing up, Edward was given the message that he was a damaged child. He began to see himself as evil and unable to meet his own standards of performance.

At the Diagnostic Center Edward was very alert to his surroundings and was able to find out exactly what was expected and would be tolerated by those adults in his surroundings. He appeared to have many skills in the areas of prosocial and antisocial behaviors. He was seen as a likeable boy who functioned in a way that brought at least 
minimal acceptance.

The recommendation for Edward was residential treatment where consistent, predictable, and sufficient controls would provide a safe and secure surrounding and a trusting relationship with one adult. Edward was especially to be removed from drugs to make clear to him that he was not a damaged individual and could begin to take responsibility for his own life.

Efforts were made by responsible social agencies to place Edward in a residential treatment facility but his mother refused and he returned home upon release from the Diagnostic Center. He was taken off drugs. A few weeks later his mother requested that her son be moved from the home because of an incident in which her car was taken. Edward was placed at St. Mary's Home for Boys for a year, where he attended special classes. A year later he was placed closer to home and then shortly was returned to st. Mary's Home for Boys where he ran away and finally was taken to MacLaren because of stealing. In 1975 he was sentenced for burglary to the Oregon state Correctional Institution where he was still residing as of August 1976. 
Case Six

Frank, male, was admitted to the Child Diagnostic Center in the fall of 1969 at the age of ten years. He was referred by a health department in southern Oregon.

Frank was known as a bright, likeable, sophisticated boy who was failing in school and exhibiting increasingly delinquent behavior in both school and in the community. He appeared to have four different personalities which ranged from the mean bully to the kind, honest boy.

At the Child Diagnostic Center Frank reacted to his new surroundings in much the same ways as had been observed prior to referral. However, by the time he left the child Diagnostic Center he had greatly improved his performance in school. The period had proven that Frank was not completely set on delinquent behavior and that much of his acting out was for attention from adults.

The recommendation for Frank was residential treatment with an effort to provide a structured and controlled setting so that he would be able to develop. A special remedial classroom would provide a program for building skills in the academic area. St. Mary's Home for Boys was a possible choice but some concern was expressed about the large size of the setting. 
Frank returned home for a year following release and then was placed at St. Mary's Home for Boys for over a year. During this time he was involved in drug use and runaway activities. Following an incident of first degree burglary he was admitted to the Oregon state Hospital for eight months. He was then admitted to the Adolescent Treatment Program at the Hospital for eleven months. While at Oregon State Hospital he committed burglary for drugs and was sent to MacLaren for a year. Here he attended regular classes as a full-time student and received counseling. However, he persisted in drug and runaway behavior. He was paroled in May 1974 and returned to his family home. Six months later he was expelled from junior high for having liquor on campus. One month later he was sent back to MacLaren for four months for stealing liquor and continued drug use and abuse while receiving some legitimate medication. In may 1975 he returned home and attended high school for his General Educational Development certificate. During this period he was working, making restitution for the burglaries, and receiving counseling from Maclaren. His parents were also receiving counseling from Maclaren to deal with their child's behavior problems. He dropped out of the GED program and recently was denied enlistment in the army, 
at the age of sixteen, because he lacked his GED.

\section{Case Seven}

Greg, male, was admitted to the child Diagnostic

Center in the fall of 1969 at the age of nine years. He was referred by a child development clinic in the greater Portland area.

Greg was a child who seemed to lack the ability to stick to a task. In school he often was restless and daydreamed continuously. In the family, Greg played the role of baby, family problem, least wanted, and rarely received any attention. The family system seemed depressed; socially and physically isolated; and turned in upon itself for all emotional support, entertainment, and activities of any sort.

During Greg's stay at the Child Diagnostic Center he functioned about two grades below his age but seemed to have normal ability and average intelligence. He appeared to have normal physical health with only minor problems of coordination. It was felt that Greg had serious disorders in his expression of emotion, in disorganized thought processes, and in his interaction with adults and peers. The recommendation for Greg was residential treatment 
which would help to provide an academic and behavioral program, including a remedial classroom. His family also needed training in child management skills, involvement in the community, and a general enrichment of their lives. Any treatment would have been ineffective if restricted to only Greg, as the whole family system was in need of help. Edgefield Iodge was seen as an excellent place for Greg but since the family did not live in Multnomah County he was not eligible for the program.

Greg returned to his family upon release and attended public school without special classes. For the past seven years he has received counseling and medication supervision from a guidance clinic in the mid-Willamette Valley and his mother has also received counseling on an off-and-on basis. The parents separated in October of 1971 and in November Greg left school because of disruptive behavior. It is reported that Greg's behavior improved eighty per cent with his father leaving the home. In the summer of 1973, he was living at home and doing odd jobs in the neighborhood. In June 1975 he stole some women's clothing from a neighbor and his mother could no longer deal with him. She requested a foster home placement for her son in July of 1975. In April of 1976 Greg moved to a northern county to live with 
his father and was no longer on medication. This living arrangement was unstable, as he ran away from his father to his mother, to a girlfriend and back to his mother. While Greg was living with his mother he did return to school and attended classes. He was achieving at the ninth grade level which was about two years below his age. As of December 1976 he had been placed in a sheltered home, ran away again, was placed in detention and finally in another sheltered home, where he experienced problems with peer relationships and still exhibited inappropriate social behavior. Long-range plans indicate a foster home placement with a male figure other than his father.

\section{Case Eight}

Henry, male, was admitted to the Child Diagnostic Center in the spring of 1970 at the age of eleven years. He was referred by the welfare department in two counties in the northern part of the state.

Henry was a victim of severe mental and physical abuse as well as neglect as a child. He suffered gross instability in his family life and finally total abandonment by his family. During his years before entering the Child Diagnostic Center, he was in several foster homes. 
Henry lacked trust and was seen as passive, enuretic and not progressing well in school. He constantly looked to adults for guidance. Often he got into arguments, attacked other children, and seemed to be easily led into trouble.

At the Child Diagnostic Center he was a charming, capable child who used his skills to engage adults. When his being-pleasant skills did not work to gain others attention he would turn to destructive behavior, having little internal standards by which he could judge appropriate behavior. He had a great need to be cared for by fondling, stroking, and just being held, due to his early deprivation. In school he was behind and gave up before starting a task. Because of his fear of being left or told he must leave again, Henry was slow to trust adults or put forth any effort to succeed at anything.

The recommendations for Henry were a small residential treatment program, thereby avoiding large living groups, and removal of drugs to control behavior. He needed an environment where he could begin to feel some security with people who would accept him as he was. Adults needed to remain available and committed to him, providing nurturance and positive reinforcement as a person. School could aid this development if school personnel also worked to structure 
his schooling with goals that he could achieve.

Henry was placed in a foster home with no attempt made to follow recommendations. In May of 1970 he was expelled from school because of disruptive behavior and poor performance but returned in september. Reportedly he was expelled in an attempt to get him into a residential treatment program. From 1970 to 1972 he received some counseling and medication supervision from a mental health clinic on the coast. Following school difficulties and problems in his foster home, he was placed in another foster home and in March of 1972 he was finally placed with a paternal uncle. Here he currently attends public school and although reportedly two years behind, plans to graduate next year. He has had success working as a ranch hand and is receiving counseling through Children's Services Division to improve his relationship with his uncle. Henry has been picked up on minor violation for possession of alcohol but was able to resolve this issue by discussion. At this time, he is no longer receiving medication since removal from the first foster home and now reports a sense of belonging and is relating well with peers. Henry's caseworker reported that for the future he will be able to live independently and hold a job with no need for further institutionalization. 
Case Nine

Issac, male, was admitted to the Child Diagnostic Center in early 1970 at the age of seven years. He was referred by a child guidance clinic in a southern oregon county.

Issac was seen as an extremely dangerous child in his first year of school. He was very assaultive and tried to stab his fellow students with a homemade knife and on one occasion he succeeded. The psychologist at the clinic described him as a homicidal risk.

In the Child Diagnostic Center, Issac was able to work well with one or two others but never with a group. In a group he tended to use foul language and ridicule to bully some children. He set up his peers for trouble, instigating fights and scapegoating. Issac seemed to have no ability to have fun and felt the need to atone whenever he hurt anyone or their property. It appeared from his performance in school that he had a normal ability to learn and to progress in his classes:

Recommendations were for residential treatment and a special classroom.

According to the director of a county mental health clinic, Issac recently returned from Alaska where he had 
been living with his father until July 1975. He has since moved to California to live with his mother who remarried. He was still having problems.

\section{Case Ten}

Jerry, male, entered the Child Diagnostic Center in spring of 1970 at the age of eight years. He was referred to the center from a mental health clinic in eastern oregon. Jerry exhibited bizarre behavior from early life. For example, he banged his head against the wall, rolled his eyes, had difficulties in motor coordination and slowness in learning. As he grew he often requested to leave home and said that he hated his parents and sisters.

At the Diagnostic Center, Jerry continued to have problems with motor control. He was a master at playing the game of crazy $\mathrm{kid}$. His behavior was bizarre and he acted in any way he could to gain positive or negative attention from peers and adults. In the final weeks of his stay at the Diagnostic Center he acted much like any normal eight year old boy.

Recommendations were for residential treatment, a special classroom for extensive individual attention, and family treatment. It was also recorded that he could benefit from extensive physical education and perception 
therapy to improve his motor control.

Jerry returned home with his parents until June 1970 when he was placed at Parry Center. Here he attended special remedial classes and did well with one-to-one relationships. From 1969 to 1970 his parents received counseling; however, they separated in the spring of 1971. In 1975 he left Parry Center for a treatment group home and special classes. Jerry was described as psychotic, delusional, and relating superficially to others. He was working a half daỳ a week and receiving counseling at the group home. In July 1976 the doctor indicated that this child was physically deteriorating because of organic causes. This deterioration has been occurring over the past several years. In addition, the mother's separation and remarriage has had an erratic impact upon the child.

\section{ANALYSIS OF FINDINGS}

Table III looks at the composite picture of the random sample of ten children from the Diagnostic Center. It presents the recommendations of the Diagnostic Center, a review of the status and condition as prepared by members of the Child Diagnostic Center staff in 1971 and finally the present status and condition as researched for this study in 1976 . 
TABIE III

TREATMENT RECOMMENDATIONS, STATUS AND CONDITION OF A RANDOM SAMPIE OF CHILDREN WHO ATTENDED THE CDC FROM 1968-70

\begin{tabular}{|c|c|c|c|}
\hline \multirow{2}{*}{$\begin{array}{l}\text { Child's \# } \\
\text { Sex \& Age }\end{array}$} & \multirow{2}{*}{$\begin{array}{l}\text { Child Diagnostic Center } \\
\text { Recommendations }(1968-70)\end{array}$} & \multicolumn{2}{|c|}{ Status or Condition } \\
\hline & & $1971 *$ & 1976 \\
\hline $\begin{array}{l}\text { \#1 Boy, } \\
8 \text { yrs }\end{array}$ & $\begin{array}{l}\text { Family counseling and training } \\
\text { plus a remedial educational } \\
\text { classroom. } \\
\text { secondary placement recommen- } \\
\text { dations for foster home or } \\
\text { treatment group home with } \\
\text { trained staff. }\end{array}$ & $\begin{array}{l}\text { Much improved. After six } \\
\text { months, child was re- } \\
\text { turned to his own home. }\end{array}$ & Status unknown. \\
\hline $\begin{array}{l}\text { \#2 Boy, } \\
6 \text { yrs }\end{array}$ & $\begin{array}{l}\text { Residential treatment with } \\
\text { parents' participation in } \\
\text { program (Edgefield Lodge). }\end{array}$ & $\begin{array}{l}\text { Still in treatment at } \\
\text { Parry Center. }\end{array}$ & $\begin{array}{l}\text { Still at Parry Center; has } \\
\text { made no progress. He will } \\
\text { need permanent institu- } \\
\text { tional care; autistic. } \\
\text { Future care in Fairview. }\end{array}$ \\
\hline $\begin{array}{l}\text { \#3 Boy, } \\
8 \text { yrs }\end{array}$ & $\begin{array}{l}\text { Family counseling, plus } \\
\text { therapeutic day care. }\end{array}$ & $\begin{array}{l}\text { Not improved: family is } \\
\text { more accepting of boy } \\
\text { since Diagnostic } \\
\text { Center program. }\end{array}$ & Deceased - no date siven. \\
\hline $\begin{array}{l}\text { \# Girl, } \\
11 \text { yrs }\end{array}$ & $\begin{array}{l}\text { Residential treatment and } \\
\text { long-term group home plus } \\
\text { special class for emo- } \\
\text { tionally disturbed children. }\end{array}$ & $\begin{array}{l}\text { Still at Christie; much } \\
\text { improved. Will need } \\
\text { stable place to live; } \\
\text { not a foster home. }\end{array}$ & $\begin{array}{l}\text { Only known details that } \\
\text { she was an unwed mother } \\
\text { on welfare. }\end{array}$ \\
\hline $\begin{array}{l}\text { \#5 Boy, } \\
11 \text { yrs }\end{array}$ & $\begin{array}{l}\text { Residential treatment and } \\
\text { cease drug therapy. }\end{array}$ & $\begin{array}{l}\text { Ceased drug therapy. } \\
\text { Improved. }\end{array}$ & $\begin{array}{l}\text { Now in Oregon state Correc- } \\
\text { tional Institution. }\end{array}$ \\
\hline $\begin{array}{l}\text { \#6 Boy, } \\
10 \text { yrs }\end{array}$ & $\begin{array}{l}\text { Residential treatment and } \\
\text { special remedial classroom. }\end{array}$ & $\begin{array}{l}\text { Recently placed at St. } \\
\text { Mary's School for Boys } \\
\text { Has stabilized. }\end{array}$ & $\begin{array}{l}\text { Dropped out of GED program. } \\
\text { Living at home. Attempt- } \\
\text { ing to get into the army. }\end{array}$ \\
\hline $\begin{array}{l}\# 7 \text { Boy, } \\
8 \text { yrs }\end{array}$ & $\begin{array}{l}\text { Family and family counseling } \\
\text { with special remedial } \\
\text { classroon. } \\
\text { secondary residential treat- } \\
\text { ment. }\end{array}$ & $\begin{array}{l}\text { still home, still psy- } \\
\text { cotic. A grave dan- } \\
\text { ger to other people; } \\
\text { will undoubtedly hurt } \\
\text { somebody in adoles- } \\
\text { cence, if not before. }\end{array}$ & $\begin{array}{l}\text { In shelter home, experi- } \\
\text { enced problem with peer } \\
\text { relationships. Long } \\
\text { range goal for him is } \\
\text { placement in a foster } \\
\text { home. }\end{array}$ \\
\hline $\begin{array}{l}\text { \#8 Boy, } \\
10 \text { yrs }\end{array}$ & $\begin{array}{l}\text { Small residential treatment. } \\
\text { Avoid large group living. } \\
\text { Remove from drugs to con- } \\
\text { trol behavior. }\end{array}$ & $\begin{array}{l}\text { Expelled again from } \\
\text { school. Some recent } \\
\text { improvement; readmit- } \\
\text { ted to school. }\end{array}$ & $\begin{array}{l}\text { Doing well, soon to complete } \\
\text { high school. Living with } \\
\text { his uncle. Receiving } \\
\text { counseling through CSD. } \\
\text { Future, he will be able } \\
\text { to live independently } \\
\text { and not need further in- } \\
\text { stitutionalization. }\end{array}$ \\
\hline $\begin{array}{l}\text { \#9 Boy, } \\
7 \text { yrs }\end{array}$ & $\begin{array}{l}\text { Residential treatment and } \\
\text { special classroom. }\end{array}$ & $\begin{array}{l}\text { still with grandmother. } \\
\text { Has stabilized. He } \\
\text { still is a homicidal } \\
\text { risk and needs inten- } \\
\text { sive treatment. }\end{array}$ & $\begin{array}{l}\text { He is living in California } \\
\text { with his mother who has } \\
\text { remarried and he is } \\
\text { still having problems. }\end{array}$ \\
\hline $\begin{array}{l}\text { \#10 Boy, } \\
7 \text { yrs }\end{array}$ & $\begin{array}{l}\text { Residential treatment with } \\
\text { family participation in pro- } \\
\text { gram (Edgefield Lodge). Spe- } \\
\text { cial classroom with special } \\
\text { attention given. Also could } \\
\text { benefit from physical educa- } \\
\text { tion, perception therapy to } \\
\text { improve motor control. }\end{array}$ & still in Parry Center. & $\begin{array}{l}\text { Physical deterioration } \\
\text { from organic causes, } \\
\text { psychotic, delusional, } \\
\text { relating superficially } \\
\text { to cthers. }\end{array}$ \\
\hline
\end{tabular}

*Material taken from report done by staff of the Diagnostic Center in 1971. 
Three of the children illustrate a present status and condition requiring continual care and protection. They very likely will spend a large portion of their lives in various institutions as they have done for the past several years. One child appears to be on the road to an independent, productive life as an adult, requiring minimal support from social agencies. Two children seem to need some type of continual intervention and perhaps will spend some time in institutions during their lifetimes. One child was reportedly deceased between 1971 and 1976. The researchers were unable to make a judgment for the remaining three children in the sample because sufficient information was not available.

Table IV presents the recommendations made by the Child Diagnostic Center and records their implementation within the first year following discharge from the child Diagnostic Center. 
TABLE IV

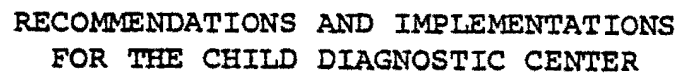

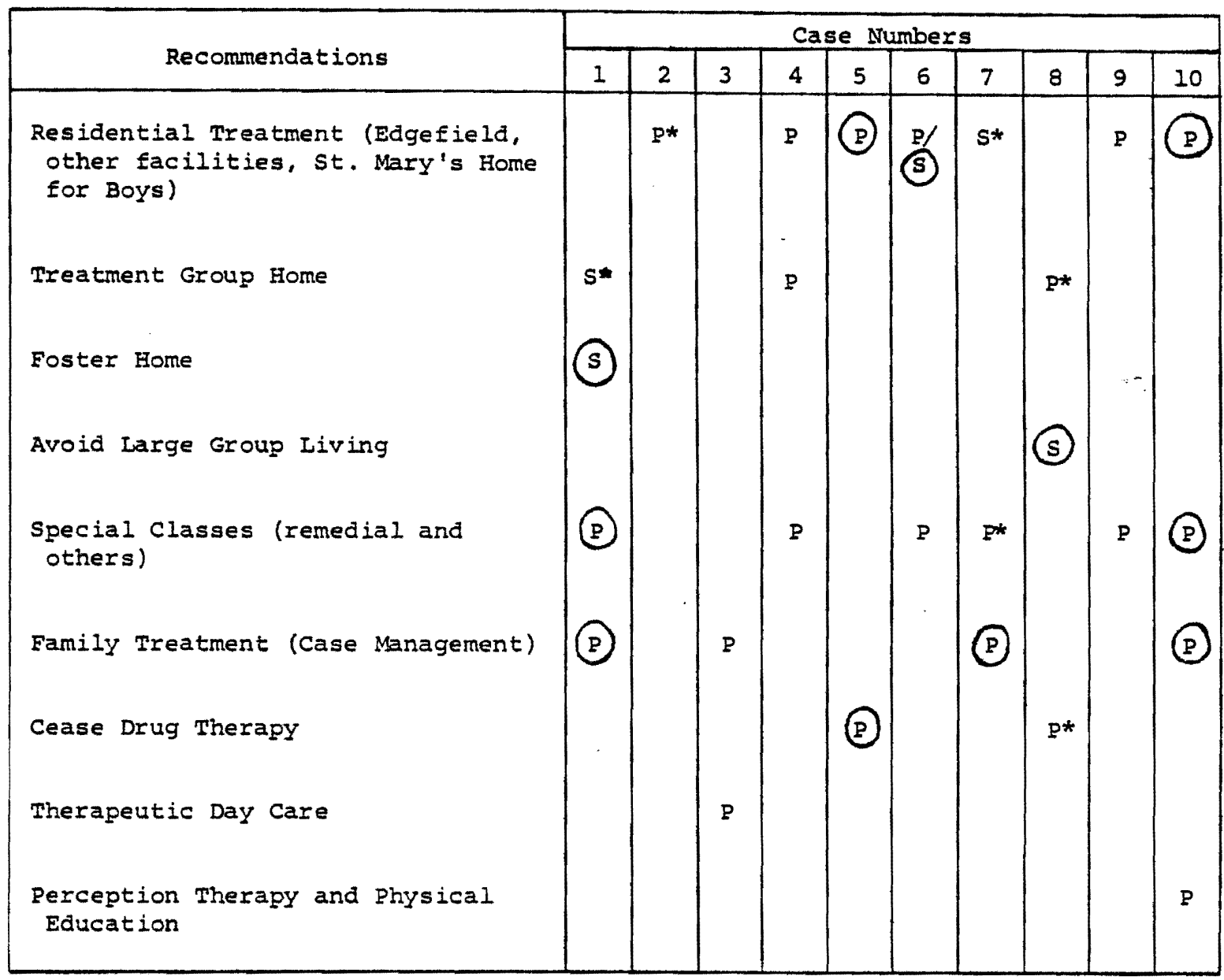

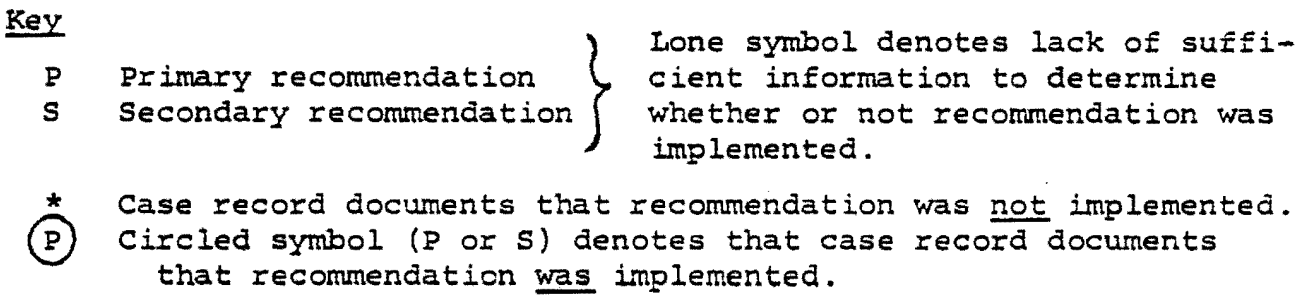

Key

Ione symbol denotes lack of suffiPrimary recommendation $\}$ cient information to determine secondary recommendation whether or not recommendation was implemented.

* Case record documents that recommendation was not implemented. (P) Circled symbol ( $P$ or $S$ ) denotes that case record documents that recommendation was implemented. 
It can be noted from the table that the most frequent recommendation was residential treatment. The second most common recommendation was for some type of special classroom, either remedial or a classroom for emotionally disturbed children. The third most frequent recommendation was for family treatment, whether the child remained in the home or was removed. Treatment group home was the next most often mentioned recommendation. The remaining recommendations were equally divided among the other categories. In looking over the recommendations, of the twenty primary recommendations, seven were followed and of the secondary recommendations, three out of a total of five were followed. Four primary and two secondary recommendations were not followed. Inadequate data leads to the inability to determine whether or not the remaining eleven recommendations were followed. 
CHAPTER VII

CONCLUS IONS

\section{DISCUSS ION}

The data does not indicate any relationship between outcomes and whether or not the Child Diagnostic Center recommendations were followed. For example, for two of the three children who at the time of the follow-up study were judged at a level of minimal functioning, the primary recommendations were implemented. The remaining child in this group did not receive the treatment specified in the recommendations. The single child who at the time of this study appeared to be the most promising, in terms of not requiring further treatment or institutionalization, did not receive the treatment specified in the primary recommendation. Rather, he was placed in a foster home (thereby avoiding large group living), a secondary recommendation. Those children who may have shown promise while at the Diagnostic Center were not able to sustain this improvement over a longer period of time, as is evident in 
Table I. The Diagnostic Center was only able to select a total of seventy-eight children out of more than seven hundred requests for admission to the facility. Only the most severe emotionally disturbed children were able to be evaluated. This fact, when coupled with a mean age of nine for the sample, may further explain the discouraging outcomes.

Since recommendations were often made for treatment outside the living area of the family, continuity between treatment plan and home life suffered. Nost of the children at one point or another during the past several years returned to their disorganized homes, often with negative results. The availability of treatment programs closer to home could have facilitated the mutual involvement of family and child in the treatment plan.

This study attempted to follow up a random sample of the total seventy-eight children who participated in the Child Diagnostic Center during its years of operation, 1968-70. In actuality, the researchers were unable to locate the entire random sample; however, the completed sample doss contain children evaluated throughout the entire period of operation of the center. The difficulties in obtaining releases and finding the other children 
necessitated the limiting of the sample to those children who were within the Children's Services Division system. The researchers had intended originally to interview the guardians of these children but due to delays in obtaining permission for information on the children it was necessary to take information from the Children's Services Division files.

The results must be viewed in light of these inherent limitations, realizing the difficulties involved with generalizing these findings for the entire population.

\section{LIMITATIONS AND OBSTACLES}

Follow-up studies by their very nature have built-in limitations. A common difficulty is an attempt to gain all the needed materials, for example, case files, addresses and consent forms, in order to do an adequate follow-up study. Access to files can be blocked by concerns surrounding the issue of confidentiality and the law, especially when it is necessary to obtain information from secondary sources, such as records from various community agencies. Releases from agency chiefs do not always guarantee that the workers throughout the different parts of the state will easily accept the release and cooperate with the study. 
Delays along the way can create time and money expense in the gathering of the data. Occasionally data will have gaps which may lead some to make interpretation as to unrecorded events. For example, it may be assumed that the lack of recorded physical problems means that the child had no physical problems during the period covered. However, the files may not mention anything to substantiate this conjecture.

All of the above were experienced in this particular study. Access to records was especially difficult for the researchers. It appeared at times that those within the mental health and children's services systems did not know how to use their own system, nor those of others, to retrieve the needed information. The retrospective nature of the study was a factor in gathering data for children who had been discharged from the Diagnostic Center from seven to nine years ago. This, coupled with the fact that implementation of the Diagnostic Center recommendations was not documented, led to gaps in information. It also limited the possibility of determining whether or not the recommendations were a factor in the treatment plan for the child. The lack of clearly defined terms, along with the change over time from ideal to practical considerations, made it 
difficult to determine whether or not recommendations had been followed.

Delays along the entire route led to a final decision to change the study, allowing for completion within the time alloted. It was decided to research files rather than gather the bulk of the data from personal interviews throughout the state.

The Mental Health Division, particularly the Child Study and Treatment Center, was in a period of transition at the time of the study. Although the practicum advisor was of great help in overcoming some of the obstacles, a lack of agency commitment greatly restricted the study. Future research would be greatly enhanced if follow-up procedures were built in at the beginning of a program, including obtaining necessary releases from those persons who are guardians of the program's participants. This would help to facilitate ownership on the part of those requesting such a study and further ensure a greater commitment to the outcomes.

\section{SUMMARY}

This follow-up study was initiated by a request from the Child study and Treatment Center of the oregon Mental 
Health Division. Its purpose was to document the consequences of the lack of implementation of specific treatment recommendations for severely emotionally disturbed children evaluated by the Child Diagnostic Center.

The random sample was limited by necessity to those children with case records within the Children's Services Division. The findings do not indicate an apparent relationship between the implementation of recommendations and subsequent outcomes.

Many of the difficulties experienced by the researchers could have been avoided if follow-up procedures had been anticipated from the inception of the program.

Follow-up studies will be increasingly important to policy making bodies in order to justify existing services and promote expansion. In addition, follow-up studies to determine program effectiveness can ultimately lead to increased skill among professionals in the delivery of services. 


\section{BIBLIOGRAPHY}

Ange11, Kristin 1976. "Oregon's Struggle Towards a Comprehensive Plan for Children's Mental Health Services: A Historical and Political Process," (Unpublished Master's Practicum, School of Social Work, Portland State University, Portland, Oregon).

Bennett, Stephen and Henriette R. Klein 1966. "Childhood Schizophrenia: 30 Years Later," American Journal of Psychiatry, CXXII, 1121-1124.

Brown, Janet L. 1960. "Prognosis from Presenting symptoms of Preschool Children with Atypical Development," American Journal of Orthopsychiatry, XXX, 382-390.

Brown, Janet I. 1963. "Follow Up of Children with Atypical Development (Infantile Psychosis)," American Journal of Orthopsychiatry, XXXIII, 855-861.

Davids, Anthony 1975. "Childhood Psychosis: The Problem of Differential Diagnosis," Journal of Autism and Childhood Schizophrenia, XV, 129-138.

DeMeyer, Marian K., Sandra Barton, William DeMeyer, James Norton, John Allen and Robert Steele 1973. "Prognosis in Autism: A Follow Up study, " Journal of Autism and Childhood Schizophrenia, XXX, 199-246.

Eisenberg, Leon 1956. "The Autistic Child in Adolescence," The American Journal of Psychiatry, CXII, 607-612.

Freedman, Alfred and Lauretta Bender 1957. "When the Childhood Schizophrenic Grows Up, "American Journal of Orthopsychiatry, XXVII, 553-565.

Goldfarb, William 1970. "A Follow Up Investigation of Schizophrenic Children Treated in Residence," Psychosocial Process, Issues In Child Mental Health, I, 9-64.

Kanner, Leo 1943. "Autistic Disturbances of Affective Contact," The Nervous Child, II, 217-250. 
Kanner, Leo 1971. "Follow Up Study of Eleven Autistic Children Originally Reported in 1943," Journal of Autism and Childhood Schizophrenia, VI, 119-145.

Lo, W.H. 1973. "A Note on a Follow Up Study of Childhood Neuroses and Behavior Disorder," Journal of Child Psychology and Psychiatry, XIV, 147-150.

Lotter, Victor 1974. "Social Adjustment and Placement of Autistic Children in Middlesex: A Follow Up Study," Journal of Autism and Childhood Schizophrenia, IV, $11-32$.

Oregon Mental Health Division 1969. Pilot Program for Emotionally Disturbed Children, (Unpublished report, Salem, Oregon).

Portland City Club Foundation, Inc. 1971. Report on Services for Severely Disturbed Children in Oregon, Portland, Oregon: Portland City Club Foundation, Inc., XIII.

Potter, Howard W. and Henriette R. Kle in 1937. "An Evaluation of the Treatment of Problem Children as Determined by a Follow Up Study," American Journal of Psychiatry, XVII, 681-689.

Rimland, Bernard 1964. Infantile Autism, New York: Appleton Century Crofts.

Rutter, Michael and Linda Lockyer 1967a. "A Five to Fifteen Year Follow Up Study of Infantile Psychosis, I. Description of the Sample," British Journal of Psychiatry, CXIII, 1169-1182.

Rutter, Michael, David Greenfield and Linda Lockyer 1967b. "A Five to Fifteen Year Follow Up Study of Infantile Psychosis, II. Social and Behavioral outcome," British Journal of Psychiatry, CXIII, 1183-1199.

Taylor, Eugene 1964. "Needed Services for Severely Emotionally Disturbed Children in Oregon," (Unpublished Report to the Mental Health Planning Board). 
SHOI INHA dV 
APPENDIX A

DATA COLLECTION FORM

Case Number

Birthdate

Sex

Date of Admittance

IQ Test Results

Physical Problems

Referral Agency

Brief Family History

Recommendations 


\section{APPENDIX B}

\section{CONSENT TO REIEASE OF INFORMATION}

I, J. N. Peet, am or was the guardian of

I authorize Nancy Peck/Krystal Angevine, as representatives of the state of Oregon Mental Health Division, to:

(1) Review any records or reports, regardless of their source, relating to the care and treatment of after his/her release from the Child Diagnostic Center in Portland on , 19 _ and

(2) Interview any individual involved in the care and treatment of after his/ her release from the Child Diagnostic Center on the above date.

I understand that any information gained from these activities is confidential and will be used only in connection with the Mental Health Division's study of the followup care and treatment provided to persons placed in the Child Diagnostic Center from 1968 to 1970 and subsequently released. I understand that my child's name will not appear in the published study.

Signed :

Date : 19 


\title{
APPENDIX C
}

\author{
QUESTIONNAIRE
}

The purpose of this research study is to find out what children's services have been used by the children who participated in the Child Diagnostic Center. The information we get from the many participants may be used to improve services for children in oregon. Your help is greatly appreciated in this important study. As you will see, none of the questions I will ask in this interview are very personal in nature; but, you can be assured that all answers are strictly confidential. No one will know how you answer the questions.

\author{
I \\ CHIID'S CASE NUMBER \\ II \\ AGE OF CHIID \\ III WHERE IS THE CHIID LIVING NOW?
}

IV WHO IS BEING INTERVIEWED?

Parent
Foster Parent
Social Worker
House Parent
Other

$V$ WHO HAS CUSTODY OF THE CHIID?

parents

Mother

Father

Court

other 
VI DOES THE CHILD HAVE CONTACT WITH ANY FAMILY MEMBERS?

Yes
No
Don 't know

If yes, with whom?

Parents

Mother

Father

Grandparents

Other

How often?

VII RACE OF CHILD

Black

White

Mixed

Mexican

Oriental

other

FOLLOW UP

\section{RECOMMENDATIONS}

\section{LIVING}

After the child left the Diagnostic Center in where did s/he go to live?

Family
Foster Home
Residential Treatment
Treatment Group Home
Other
What was the date when
began living at
How long was s/he there?
What was the date when $s /$ he
left?


Now I am going to ask you some specific questions about what happened while child was living at like to know only about the time I would was living at from to - First let me ask you about 's school experiences while $\mathrm{s} / \mathrm{he}$ was living at

\section{RECOMMENDATIONS IX SCHOOL HISTORY}

When was living at was $\mathrm{s} /$ he in public school?

Yes
No
Don't know

Did the child attend more than one school while s/he was living at Yes No

If yes, how many?

Why did the child attend schools?

If yes, I am going to ask you some questions about the first school. Please answer the questions only about the first school.

What was the date when $s /$ he started school there?

Date

How long did s/he go to school there?

Optional: why did $s /$ he leave school?

Was the child in a special education classroom?

Yes Don't know No 
RECOMMENDATIONS

RECOMMENDATIONS
If yes, what kind of classroom?

Special Classroom

Remedial Classroom

Special Remedial Classroom

Don't know

Did the child remain in the special classroom as long as $\mathrm{s} /$ he attended school there?

Yes

No, explain

If NOT in public school, what kind of school did $s /$ he attend?

What was the date $s /$ he started school there?

How long did $s /$ he go to school there?

(Optional) Why did s/he leave school?

Was the child in any special classroom?

Yes

No

Don't know

If yes, what kind of classroom?

Special Classroom

Remedial Classroom

Special Remedial Classroom

Don 't know

Did the child remain in the special classroom as long as $\mathrm{s} /$ he attended school there?

Yes

No

Don't know

If no, explain. 
RECOMMENDATIONS

Did the child miss school for any reason besides sickness?

Yes

No

Don't know

If yes, for what reason?

How many days per week were missed?

Did the child get into any trouble with school authorities?

Yes

No

Don't know

If yes, what kind of trouble?

Did the child have any tutors?

Yes

No

Don't know

If yes, why did the child have a tutor?

When did $s /$ he first get the tutor?

How long did $s$ he have the tutor?

If the child was NOT in school, why was the child not in school?

What was the date the child left school?

How long was $s /$ he out? 
RECOMMENDATIONS

$\mathrm{X}$ EMPLOYMENT

When the child was living at was $s /$ he employed in any way? Yes

No Don't know

If yes, what type of job did $s /$ he have? When did the child begin working there?

How long did $s /$ he work there?

Why did $s /$ he stop working there?

During the time the child was living at else beside was $s /$ he employed anywhere

Yes

No

XI TROUBLE WITH THE LAW

During the time the child was living at did $s /$ he get into any trouble with the law?

Yes

No

Don't know

If yes, what kind of trouble?

When?

What was the result?

Was that the only time the child got in trouble with the law while $\mathrm{s} / \mathrm{he}$ was living at 
XII COUNSELING OR TREATMENT

During the time the child was living at did $s$ he get any counseling or treatment from any agency? Yes

No Don't know

If yes, what kind of counseling or treatment?

What kind of agency?

What was the date when $s /$ he . began?

How long did $s /$ he continue?

Did the child have any other counseling while s/he was living at ?

Did the child have a Big Sister/Brother or college companion?

Yes

No Don't know

XIII PHYSICAI NEEDS

During the time the child was living at did $s /$ he see a doctor for any major illness or physical problem? Yes No Don't know

If yes, what was the problem?

When did it occur? How long did it last?

Did the child have any other major illness or physical problems while $s /$ he was living at 


\section{RECOMMENDAT IONS}

XIV
FAMIIY COUNSEIING OR TREATMENT

During the time did his or her family receive any type of family counseling or treatment?

Yes

No

Don't know

If yes, what kind?

From what kind of agency?

Who received the counseling?

The whole family together parents Mother Father other When did they begin counseling? How long did the counseling last?

Why did they stop?

Did the family have any other counseling or treatment while the child was living at ?

XV SIGNIFICANT HAPPENINGS

Did anything else significant happen to the child while $\mathrm{s} /$ he was living at ? Yes

No Don't know

If yes, what was it?

When did it happen?

How long did it last? 


\section{RECOMMENDATIONS XVI LEAVING}

Why did the child leave ?

After the child left where did $s /$ he go to Iive?

CONCLUSIONS

XVII GRADE IEVEL

Does the child have a high school diploma?

Yes
No
If not why not?

Does the child have the GED?

Yes

How far has the child gotten in school?

XVIII RECOMMENDATIONS

Did you at any time try to get the child

Yes

No

If yes why was the attempt unsuccessful? 
Describe the child's relationship with others.

XVX FUTURE

How do you see the future of the child?

Living independtly?

Employed?

Problems?

Other 